\title{
Public Relations Opportunities for Schools Utilizing Innovations in Virtual Communities
}

\author{
Frances L. O’Reilly ${ }^{1} \&$ John J. Matt ${ }^{1}$ \\ ${ }^{1}$ Department of Educational Leadership, The University of Montana, Missoula, Montana, USA \\ Correspondence: John J. Matt, 32 Campus Dr., Department of Educational Leadership, The University of \\ Montana, Missoula, Montana, 59812, USA. Tel: 1-406-243-5610. E-mail: john.matt@umontana.edu
}

Received: March 15, 2013

Accepted: April 7, 2013 Online Published: May 2, 2013

doi:10.5539/jel.v2n2p139

URL: http://dx.doi.org/10.5539/jel.v2n2p139

\begin{abstract}
With the dawn of the Information Age, schools, along with other organizations, must take note of the varied ways individuals and groups in society are communicating. Today, with the many forms of communication, most information is made public in real time. In a qualitative national study in the United States, respondents identified positive and negative aspects stemming from comments in virtual communities that impact school district public relations. School superintendents indicated a clear need for schools to become cognizant of and involved in virtual communities. While acknowledging the need and some supportive ideas, the respondents identified the barriers to involvement as time and personnel. The authors have proposed a systematic process, as a result of study data that will allow school leaders to take a proactive approach to public relations in virtual communities.
\end{abstract}

Keywords: public relations, virtual communities, education, schools, educational leaders

\section{Introduction}

In the $21^{\text {st }}$ century school leaders must be interactive with their external and internal publics. "The advent of the Internet has dramatically changed the way public relations practitioners distribute information, interact with key publics, deal with crises, and manage issues" (Hallahan, 2004, p. 1). In the past schools were solely under the purview of the education community. Parents, non-parents, taxpayers, classified staff and the many other constituents were not consistently apprised of, or included in the education process. In some cases information was only disseminated by the school districts if it was requested. According to Kowalski (2008) and Grunig (1984) the most effective type of Public Relations in schools is two-way communications. This type of communication better enables all parties to come to a mutual understanding and resolve conflict in a more collaborative manner. "Today, when public support cannot be taken for granted, schools and school systems must find ways to build and strengthen connections with their communities. The foundation for strengthening connections and improving relationships is proactive communication" (Meek, 1999, p. 2-3)

With the dawn of the Information Age, schools, along with other organizations, must take note of the varied ways individuals and groups in society are communicating. Today, with the many forms of communication, most information is made public in real time.

The Internet has no government or ethical regulations controlling the majority of its available content. This unregulated flow of information presents a new problem to those seeking information, as more credible sources become harder to distinguish from less credible sources. (Andie as cited in Eastin, 2001).

Too often the information may not even be correct but in a virtual arena, without a knowledgeable response, it becomes the reality. In the absence of the truth, people fill in the gaps and begin to make up the data and the scenarios from which the data emerges. "Those who are able to understand the power of the [electronic] grapevine will be better prepared to utilize it to provide stability and credibility in the work environment that is needed in order to achieve organizational goals" (Mishra, 1990, p. 213).

\subsection{Significance of the Study}

Social networking has become an important means of communication. Since the advent of the millennial generation, born between 1982 and 2001 (Strauss \& Howe, 2000), the world has always utilized digital interaction and media. The Millennials are native digital users; it is second nature to them. Internet usage 
worldwide in the last decade has shown marked increases. North America alone shows an increase of $146 \%$ from 2000-2010 (internetworldstats). From June 2009 to June 2010 social networking activity, as shown by Nielson (2011) has increased by $43 \%$. Information now travels at the speed of light, information sources are "always on" and the digital native is "always connected." Unlike previous generations where face-to-face interaction was paramount, this generation does much, if not most, of their interactions through digital media. Immigrants to digital media, who are interested in sharing information regarding individual school districts or, for that matter, education in general, will need to master digital media and understand how internal and external publics receive and process information in this new paradigm.

"Online access has created new pressures on school communicators to be timely and transparent in their communications" (Moore, Gallagher \& Bagin, 2012, p. 217). As a result, key communicators for the district need rapid access to information to respond in an appropriate manner for rapid-fire information transfer. There are many facets to online information transfer brought about by the swift growth and diverse functionality of the internet. This study was delimited to the role virtual communities played in public opinion about school districts.

Some superintendents use social media and blogs to connect with stakeholders. While administrators and teachers can use social media and blogs to share information with their stakeholders and students, monitoring social media and blog postings is an important way to collect feedback. Monitoring service that use key words to alert subscribers to new postings about an organization or an issue, such as Google Alerts...or Yahoo Alerts...can help school communicators track online postings from traditional news source[s], social media and blogs (National School Public Relations Association as cited in Moore, et.al., 2012, p. 228).

\section{Methodology}

A questionnaire was developed for this qualitative study and superintendents responded to questions regarding the impact, availability and usage of virtual communities in their school district (Gay, Mills \& Airasian, 2012). Some descriptive quantitative data was also included. Hsieh and Shannon (2005) posited, "a research method for subjective interpretation of the context of text data through a systematic classification process of coding and identifying themes or patterns" (p. 1278) is the prominent qualitative methodology the researchers employed. Patton (2002) indicated qualitative research is "any qualitative data reduction and sense-making effort that takes a volume of qualitative material and attempts to identify corer consistencies and meanings" (p. 453). This methodology, which is mainly inductive, grounded the examination of this data in topics or themes and the inferences drawn from the data (Bogden \& Biklen, 1998). Basic text was codified during the content analysis and general categories were generated and modified from the responses in the analysis and new categories emerged (Miles \& Huberman, 1994). The questionnaire contained open-ended questions, Yes/No response and fill-in-the-blank questions. The initial contact was via email with a survey link embedded. A link to the digital questionnaire was sent to the director of each state administrative organization for the school districts (i.e. School Administrators of Montana, Confederation of Oregon School Administrators, Etc.). The directors were asked to forward the survey to each superintendent in their state. The survey was taken anonymously through Surveymonkey. There were a total of 73 responses from across the country. Three weeks later, a follow-up email was sent to those who had not yet responded.

\section{Findings}

The participating superintendent's estimated the average percentage of households having internet access was $61.14 \%$ (median $=63.5 \%$ ). According to Nielsen (2011) the actual percentage of homes in the United States that have Internet access is $74.9 \%$. This represents a $13.5 \%$ disparity between the national percentage and the estimates of the participating superintendents. In this study, the relationship between level of poverty, as defined by percentage of students eligible for the free and reduced lunch program, and the superintendent's estimate for the percentage of homes that have internet access was inverse $\left(r=-0.46 ; r^{2}=.21\right)$. As poverty increased the estimate of internet connectivity declined. This non-probability sample showed that the participating school districts had less internet access in the student homes than the national average. This study showed that up to $21 \%$ of the predictability of estimated internet access in the home can be attributed to economic status.

Although participant comments were evenly split between positive and negative impacts of virtual communities, the negative comments like, "Although [virtual communities] appear to be positive it only takes one critic without the facts to bury a district's reputation" encapsulates the tone of the open-ended responses. As one respondent stated, "There is one site that we do have to monitor from time to time to verify an accusation or if someone has crossed the line." Another respondent said "when inaccurate information has been posted by others, by monitoring virtual communities districts have been able to combat negative information."

It appears from the responses in this study school leaders are underestimating the impact of what is discussed in 
virtual communities and how it affects public opinion of their districts. In the districts surveyed, only $18 \%$ indicated that they had designated someone to monitor discussions in virtual communities. Of that $18 \%$ only 5.5\% had the task assigned to someone as a specific job duty. Some of the titles given to these designees were Public Relations Officer and Web Master, Systems Coordinator, teacher, and IT person. In these responses, while it is an added job duty, at least someone is assigned to oversee this arena.

In light of the themes that were evinced from the qualitative data, school leaders need to consider revising their approach to public relations in light of changing technology in the media. Technology offers school districts a wider variety of public relations opportunities but also creates forums for discussion that can go unnoticed or unaddressed by school officials. An interesting side note is that if there is no response to untrue or erroneous information, those people involved in the discussion often believe the information to be true. Daily and weekly newspapers across the country have begun to allow follow-up commentary on articles that appear in on-line editions. These commentaries, unlike the usual "letter to the editor," can occur quickly and too often, anonymously. This issue with these commentaries is reflected in the following statements of some of the study participants: "The anonymity of online sites does not promote positive comments" and "[on-line comments are] very negative since it is always anonymous and emotional."

These forums are often well "attended" by community members. In a time when accountability is a vital consideration in education, it is incumbent for school districts to be actively involved in all the forms of communication. These interactions will help to forge a more collaborative environment and realistic partnerships with the public. As one of the superintendents indicated in a survey response, "when controlled adequately, [the impact of the virtual community is] mostly positive."

Positive statements made by study participants who engage in virtual communities include: (a) "[virtual communities] generate discussion which can lead to better understanding of issues;" (b) "[virtual communities] provide an avenue for gauging public perceptions;" (c) "parents really seem to appreciate having immediate access to information;" (d) "[we] do surprisingly find that some folks do offer a different viewpoint or opinion;" (e) "[virtual communities] allow our stakeholders to have a voice and to be heard;" and (f) "[virtual communities have]an impact on those who do not have children in school."

In communities with daily newspapers, the comment period is short and will likely generate a brief controversy. In communities with weekly newspapers, the comment period lasts much longer giving more opportunity for community members to read the comments and weigh in on the issue. Some newspapers will retain an article on their web page long after the next edition has been posted if the article is drawing significant discussion.

This new paradigm in media processes can be troublesome for those concerned with school district public relations. This can also create opportunities if school districts take a proactive approach to dealing with the issue. Many school districts have developed a network of "key communicators" that hold prominent positions in the community and volunteer to listen to the community and gauge the issues that are being discussed. They then use their voice in the community to be sure that accurate information is being understood by community members. In response to the new media process, school districts need to form a committee of volunteers who are willing to interact on-line in response to on-line comments that, if left unaddressed, would result in propagation of inaccurate or biased information.

This Public Relations Committee does not need to be large. If six people were to dedicate one hour per week (or 12 people 1 hour every two weeks) the majority of the comments could be addressed. In addition, those articles that show the positive aspects of the school community could be enhanced by appropriate follow-up comments. (O'Reilly \& Matt, 2011, p. 28)

\section{Creating an Oversight Committee for Virtual Communication}

To create this committee: (a) Identify community members from all facets of life who have the ability to influence others. (suggestions: Retail clerks, hair dressers, medical workers, business owners, school board members, parents); (b) Invite these potential committee members to an informational meeting to collaboratively assess their willingness and ability to participate on the committee; (c) Use role play to illustrate the handling of potential public relations situations that could occur in virtual communities; (d) Select committee members based on willingness, availability and time constraints; (e) At the initial meeting of the selected committee members will agree on the structure and timeframe for communication with district administrators on public relations matters; (f) Create a plan with goals and objectives. Include a timeline for committee members to access the on-line local newspaper and applicable virtual communities and to address the issues being discussed; and (g) Meet periodically for oversight assessment and to realign the role of the committee if necessary. 
When administrators have cultivated and nourished a positive relationship with the media publics, it is more likely that they will have knowledge of an article about the district before it is published. It is incumbent upon the school leader to communicate with the Public Relations Committee prior to the publication of an article, to advise them of the issues that will be discussed in the article, and provide them with the information to support the school's position. In these situations, communication with the committee ahead of time will help in the planning and preparation of responses that accurately reflect the correct information regarding the issue.

As with any committee in the school district, for collaborative efforts to be successful, it is important to meet face-to-face periodically to establish and maintain a common focus, and pursue goals and objectives that enhance the School District mission and vision. Zhao (2009) indicated that time is a factor that is accelerating: In 1492 it took Columbus 3 months to cross the Atlantic, while today this can be accomplished in less than 13 hours and with the Internet, less than a second. Because of the speed of information transfer it is imperative that these on-line responses are monitored daily. School leaders must maintain contact with this committee to keep them informed and up-to-date on school issues. They must also be consistent in thanking them and giving recognition to the committee for their expertise and time. One caution, if state open meeting laws apply to this committee it is important to abide by those laws.

Public Relations Committee members will interact with constituents in designated virtual communities and the district will have capitalized on a golden opportunity to be in two-way communication with the district's constituents. In addition, committee members will be able to respond in a timely manner to unfair and erroneous information as well as to positive comments. In a time when the modes of communication are multifaceted and school districts are under fire for a variety of issues, it is incumbent for school districts to employ every means at their disposal to communicate and collaborate with their internal and external publics. According to Moore, et.al. (2012):

The persuasiveness of a communication is greater when certain things are known about the communicator. This is usually the case if the sender has gained a reputation for being honest and direct...is thought to be well informed on the subject of the message, or shares a common background or set of experiences with his or her listeners. (p. 80)

Respondents in this study also identified a myriad of virtual communities that are utilized and have an impact on the public relations of their school districts. These virtual communities included: Greatschools.com, BlackBoard Connect, Facebook, Wikis, Topix, MySpace, School district websites, community websites and Twitter. Depending on the extent of use of these sites, the committee may seek to engage in these venues as well.

This study has brought to the forefront the emerging arena of on-line public relations issues facing school leaders. While some school leaders have embraced the new digital paradigm, the role of on-line newspaper comments in the perceptions of stakeholders has not, according to the respondents, been taken seriously enough. It is imperative that a school district public relations plan include a well-developed strategy for responding in virtual communities.

\section{References}

Bogden, R., \& Biklen, S. (1998). Qualitative Research in Education: An introduction to theory and methods (3rd ed.). Needham Heights, MA: Allyn \& Bacon.

Eastin, M. (2001). Credibility Assessments of Online Health Information: The Effects of Source Expertise and Knowledge of Content. Journal of Computer-Mediated Communication, 6(4).

Gay, L. R., Mills, G. E., \& Airasian, P. (2012). Educational Research: Competencies for Analysis and Applications. Boston, MA: Pearson.

Grunig, J. E. (1984). Organizations, environments and models of public relations. Public Relations research and Education, 1, 6-29.

Hallahan, K. (2004). Protecting an organization's digital public relations assets. Public Relations Review, 30(3), 255-268. http://dx.doi.org/10.1016/j.pubrev.2004.04.001

Hsieh, H., \& Shannon, S. (2005). Three approaches to qualitative content analysis. Qualitative Health Research, 15(9), 1277-1288. http://dx.doi.org/10.1177/1049732305276687

Kowalski, T. J. (2008). Public relations in schools. Pearson/Merrill/Prentice Hall, Columbus, Ohio.

Meek, A. (1999). Communication with the Public: A Guide for School Leaders. Alexandria, VA.: Association for Supervision and Curriculum Development 
Miles, M., \& Huberman, A. (1994). Qualitative Data Analysis. Thousand Oaks, CA: Sage Publications.

Mishra, J. M. (1990) Managing the grapevine. Public Personnel Management, 19(2).

Moore, E., Gallagher, D., \& Bagin, D. (2012). The school and community relations. Pearson/Allyn and Bacon. New Jersey.

Nielsen. (2011). Retrieved from Nielsen//NetRatings http://www.nielsen-online.com/pr/pr_040624_italy.pdf

O’Reilly, F., \& Matt, J. (2011). Revising PR's Approach Using New Media Tools. The Illinois School Board Journal, 79(4), 26-29.

Patton, M. Q. (2002). Qualitative Research and Evaluation Methods. Thousand Oaks, CA: Sage Publications.

Strauss, W., \& Howe, N. (2000). Millennials Rising: The Next Great Generation. Vantage Books: New York.

Zhao, Y. (2009). Catching Up or Leading the Way: American Education in the Age of Globalization. ASCD: Alexandria, Virginia. 